\title{
THE ROMAN IMPERIAL COURT: SEEN AND UNSEEN IN THE PERFORMANCE OF POWER ${ }^{1}$
}

\author{
Andrew Wallace-Hadrill
}

\begin{abstract}
Reflect continuously how everything of the same sort as what happens now, also happened in the past, and think of how it will happen again; put before your eyes whole dramas and scenes of the same types you have encountered in your own experience or in ancient history, such as the whole court of Hadrian and the whole court of Antoninus and the whole court of Philip, Alexander and Croesus. All of them were of the same sort, only the people were different. ${ }^{2}$
\end{abstract}

An emperor, if anyone, should know. All the world's a stage, and the court he knew was only a specific re-enactment of a drama or scene that had played in the past and would play again in the future. We could hardly ask for a stronger or more authoritative invitation to consider courts as a cross-cultural phenomenon. Gibbon indeed seems to have taken the message, in a chapter that gives a devastating account of the ceremonials of the court of Constantine and his successors, marking the degeneration of the 'manly pride' of the Romans into the condition of 'abject dependents':

By a philosophic observer, the system of Roman government might have been mistaken for a splendid theatre, filled with players of every character and degree, who repeated the language, and imitated the passions, of their original model.

Gibbon's footnote points to 'Pancirolus ad Notitiam utriusque Imperii'; but in this last sentence, it is not the sources for ceremonial he is thinking of, but the philosophic emperor Marcus. Tacitly, the authority of

\footnotetext{
${ }^{1}$ I have preserved the text of my paper as delivered in Istanbul with only minor modifications to take into account more recent publications. I am grateful both to the organizers of the conference, and to Jeroen Duindam for discussion.

${ }_{2}$ Marcus Aurelius Meditations 10.27. On which see P.A. Brunt, 'Marcus Aurelius in his Meditations', Journal of Roman Studies 64 (1974) pp. 1-20; A.S.L. Farquharson, The Meditations of Marcus Aurelius (Oxford 1944) vol. 2, pp. 845-846 ad loc.; Aloys Winterling, Aula Caesaris. Studien zur Institutionalisierung des römischen Kaiserhofes in der Zeit von Augustus bis Commodus (31 v.Chr.-192 n.Chr.) (Munich 1999) pp. 1-3.
} 
the emperor of the Romans at their manly best is used to condemn the degeneration of the later Empire. ${ }^{3}$

Marcus' assertion of continuity was right in more senses than one: it is not just that imperial courts had a generic similarity to other royal courts, but that there were strong ties of historical continuity that linked the Roman court to those of the Hellenistic east after Alexander, and to the Persian court which Alexander's conquests absorbed and incorporated; and his prediction of future re-enactments was true in the stronger sense that the imperial court would provide models for the Byzantine, papal and early medieval courts, which in turn would influence the courts of absolutist Europe, and through Byzantium, the Ottoman and Russian courts. ${ }^{4}$ Constantinople is a good place to reflect on Marcus' prescience.

Nevertheless, Roman historians have, at least until very recently, either ignored the imperial court as a phenomenon, or dismissed its importance, or even denied it. This much has now been shown in detail by the recent studies of Aloys Winterling, Aula Caesaris and Mario Pani, La Corte dei Cesari. ${ }^{5}$ Winterling in particular shows how despite the attention drawn by Ludwig Friedlaender to the imperial court as the central phenomenon of Roman imperial society, Roman historians continued to follow the lead of Mommsen, who excluded the court from his Staatsrecht on the grounds that it was not a legally-based institution. ${ }^{6}$ Mommsen was quite right: the court had no place whatsoever in the Roman constitution. On the other hand, Roman imperial history is incomprehensible without it, and the correct inference to draw was that a legal/constitutional approach was not appropriate for Roman imperial history. A century and more of post-Mommsenian

${ }^{3}$ Edward Gibbon, The Decline and Fall of the Roman Empire, John Bagnell Bury, ed. (London 1896) vol. 2, p. 160 with n. 77.

${ }_{4}$ There is a notable lack of a comparative study of such courts. A welcome first step (published after this conference) is Antony S. Spawforth, ed., The Court and Court Society in Ancient Monarchies (Cambridge 2007). See my review in The Court Historian [Andrew Wallace-Hadrill, 'Courts and Classicists', The Court Historian 14, 1 (2009)]. For a comparative perspective on early modern courts, see Jeroen Duindam, Vienna and Versailles: the Courts of Europe's Dynastic Rivals, 1559-1780 (Cambridge 2003); Reinhardt Butz, Jan Hirschbiegel and Dietmar Willoweit, eds., Hof und Theorie: Annäherungen an ein historisches Phänomen (Cologne; Weimar; Vienna 2004) and further literature cited below n. 23.

${ }^{5}$ Mario Pani, La corte dei Cesari fra Augusto e Nerone (Rome; Bari 2003).

${ }^{6}$ Winterling, Aula Caesaris, pp. 12-18. 
historiography was based on the false premise that one could only access Roman imperial rule through its legal, constitutional and bureaucratic structures. The drama which Marcus continuously had before his eyes was thus veiled from sight.

It is worth asking why modern historiography has chosen to ignore a power-structure about which the ancient sources speak plainly and repeatedly. ${ }^{7}$ Beyond Mommsen's influence is an interesting convergence of ideologies, between modern liberalism and ancient republicanism. For the modern world, antiquity has been a critical source of models of anti-monarchical systems: Roman republicanism and Athenian democracy are such cornerstones of modern ideology that we do not want to hear that the imperial court has had a longer, deeper and wider influence. Here modern ideology finds convenient confirmation in the republicanism of Tacitus. By his ironical tactic of narrating from the perspective of the constitutional organs of the Roman state, the senate and people, he denies the legitimacy of the court, around which nevertheless, as his narrative reveals, the entire action revolves. From Mommsen on, Roman imperial history has been told from an insistently Tacitean perspective. When Fergus Millar deliberately broke from that perspective in the Emperor in the Roman World, and adopted instead the perspective of Greek writers like Dio, his claim that the imperial system (normally referred to, for equally ideological reasons, as 'the Principate') was in fact a form of monarchy was regarded as controversial. ${ }^{8}$ I believe we can now take it for granted.

The imperial court, then, was something Roman historians knew about but preferred not to discuss, the skeleton in the cupboard of Roman history. Even Paul Veyne, who saw imperial rule as a form of monarchy, made the explicit comparison with the court of Louis XIV, on which his friend Le Roy-Ladurie was working, and concluded that the Palatium was no Versailles, and that the true court of Rome was

\footnotetext{
7 On the explicit ancient discussion of the court, see Winterling, Aula Caesaris, pp. 194-203; Andrew Wallace-Hadrill, 'The Imperial Court', in: Cambridge Ancient History new ed. vol. X (Cambridge 1996) pp. 283-308, esp. pp. 283-285; Jeremy Paterson, 'Friends in high places: the creation of the court of the Roman emperor', in: The Court and Court Society in Ancient Monarchies, Antony S. Spawforth, ed. (Cambridge 2007) pp. 121-156, esp. pp. 123-126.

${ }^{8}$ See also Fergus Millar, 'Emperors at Work', Journal of Roman Studies 57 (1967) pp. 9-19.
} 
the Colosseum, the emperor with his people at the games. ${ }^{9}$ One might as well say that the true court of Ferdinand IV of Naples was the popular spectacle of the Cuccagna, when the starving Neapolitans tore apart heaps of living animals in the piazza, and not the Reggia at Naples or Caserta. Public spectacles are fine for a display of power, but do not touch on the crucial function of the court, which is the concentration and redistribution of power. The Palatium remains the single largest structure in Rome, and until we can get our heads around it, alongside its familiar neighbours the Colosseum and the Forum, we cannot understand how or why the Roman empire worked. ${ }^{10}$

That the court was not examined analytically as a system of concentration and redistribution of power is the stranger in view of the turn taken by Roman republican historiography. Particularly in the acute formulation of Matthias Gelzer, the Roman republican nobility was seen as a system of reproducing social power. ${ }^{11}$ Power was conceived as dependent on the control of the magistracies, especially the consulships. Gelzer demonstrated the strong tendency for descendants of consuls, the self-styled nobiles, to dominate high office (and in consequence opportunities for military command, enrichment and religious and social prestige). He attributed their success to the system of patronage whereby networks of friendship and ties of vertical dependence were activated to procure votes in the elections. This thesis has more recently come under sustained attack by Peter Brunt and Fergus Millar, and at the least we must admit that the mechanism of clientela was simplified mechanically by Gelzer; even so, it remains a characteristic of the last century of the Republic that office, influence and power were kept within a limited circle of dominant families. ${ }^{12}$

The paradox is that if access to high office was seen as the key to the Republican power system, access to office should also be the key

9 Paul Veyne, Le Pain et le Cirque (Paris 1976) pp. 682-685; cf. Emmanuel Le Roy Ladurie, 'Versailles observed: the court of Louis XIV in 1709', in: The Mind and Method of the Historian, S. and B. Reynolds, trans. (Brighton 1981).

${ }_{10}$ See Claudia Cecamore, Palatium: topografia storica del Palatino tra III sec. a.C. e I sec. d.C. (Rome 2002); Ricardo Mar, El Palatí: la formació dels palaus imperials a Roma (Tarragona 2005). It is the focus of an important new project by the German Archaeological Institute in Rome.

${ }^{11}$ Matthias Gelzer, Die Nobilität der römischen Republik (1912), translated R. Seager, The Roman Nobility (Oxford 1969).

${ }_{12}$ P.A. Brunt, The Fall of the Roman Republic and Related Essays (Oxford 1988) pp. 382-442; Fergus Millar, The Roman Republic and the Augustan Revolution (Chapel Hill; London 2002) pp. 109-61. 
to the imperial system. How and where did individuals access office, influence, and wealth? The answer, evidently, is that such things now depended not on the popular vote but imperial favour. Since epigraphy provides abundant evidence on the personnel involved, the prosopographic instinct, which in the case of republican power-holders focused on the networks and intrigues by which groups held power, was focused in the case of the empire on bureaucratic systems: endless volumes on Kaiserliche Verwaltungsbeamten catalogued a supposed imperial bureaucracy at every level, from senatorial office holders to equestrian officials and procurators, to the vast army of imperial freedmen and secretariat. ${ }^{13}$ Arnaldo Momigliano's short biography of Claudius, first published in 1932, is eloquent on the Tendenz of this approach. He presented Claudius as a great bureaucratic reformer, and refused explicitly to consider the abundant evidence of court intrigue, specifically that involving female members of the imperial family and freedmen. ${ }^{14}$

Yet at exactly the same moment, Robert Graves was using this material for his memorably vivid evocation of the imperial court in I Claudius. ${ }^{15}$ The intrigues of the imperial court were evidently material for historical novels, not for serious history. But there was another, ideological, factor at play. Momigliano, writing in Mussolini's Italy, wished to defend empire and the imperial system, even in the hands of one whom the outside world might regard as something of a buffoon; Graves, writing from an anti-fascist perspective, wished to expose imperial power as a web of intrigue. What most demands explanation is why Roman historians writing after the war still refused to confront the realities of imperial power. The defensive tone became stronger, and with it the representation of that power as a logical bureaucratic system. Even Syme, so fearless in the 1930s in exposing the foundations of imperial power in party factionalism, and who read for amusement the memoirs of the Versailles court of Saint-Simon (so he told me), fails in his Tacitus volumes to tackle head-on the phenomenon of a court system.

\footnotetext{
13 See Winterling, Aula Caesaris, pp. 23-6.

14 Arnaldo Momigliano, L'opera del imperatore Claudio (Firenze 1932), translated W.G. Hogarth, Claudius: the Emperor and his Achievement (Cambridge 1961).

${ }^{15}$ Robert Graves, I Claudius, first published 1934.
} 
Millar's Emperor in the Roman World was the first book to confront imperial power as a system of distribution of office, wealth, favour and judgement, and even then, he left it to Richard Saller to spell out the mechanisms of patronage and clientelism on which such a system must rest. ${ }^{16}$ For all Millar's emphasis on the personal actions of the emperor, it is evident that he could not distribute hundreds of offices and benefices without a web of recommendations. Saller spelled out the system of brokerage whereby recommendations were filtered to the emperor, in a chapter tellingly entitled, 'The emperor and his court'. But again, though he vigorously contests the thesis of any bureaucratic system of promotion, and argues for benefices and access to justice mediated by brokers ranging from members of the female family and potent freedmen to favoured members of the elite, he stops short of offering a conceptualization of the court as system. ${ }^{17}$

It was in studying Suetonius' imperial biographies that I was struck by how casual and persistent was the idea that the emperor was surrounded by a court, and that the court was the arena in which power was traded..$^{18}$ As an imperial secretary under Hadrian, the author might be assumed to have a reasonable understanding of the workings of the court; nor did he share the apparent disdain of the senatorial Tacitus for dealings that took place outside the senate. What he offers, after his fashion, is not analysis, but a series of vivid snapshots. The word aula, court, and its derivatives are recurrent. It is from the intimi aulici, intimate courtiers, of Caligula that Suetonius' own grandfather had heard the emperor's reason for building the bridges of boats across the bay of Naples: the astrologer Thrasyllus had said Caligula would no sooner be emperor than ride on horseback across the bay (Cal. 19.3). Claudius was a figure of fun at Caligula's court (Tacitus uses the expression inter ludibria aulae): he used to fall to sleep and snore at dinner, so the jesters put boots on his hands so he would rub himself with them when he awoke (Claud. 8). Otho owed his promotion to feigning love for an influential court freedwoman, libertinam aulicam gratiosam, despite the fact she was over the hill; hence he insinuated himself into

\footnotetext{
${ }^{16}$ Fergus Millar, The Emperor in the Roman World (London 1977); Richard P. Saller, Personal Patronage under the Early Empire (Cambridge 1982).

${ }_{17}$ Saller, Personal Patronage, pp. 41-78; see also Andrew Wallace-Hadrill, 'Patronage in Roman society: from republic to empire' in: Patronage in Ancient Society, Andrew Wallace-Hadrill, ed. (London 1989) pp. 63-87.

${ }^{18}$ See Andrew Wallace-Hadrill, Suetonius: the Scholar and his Caesars (London 1983) pp. 177-80.
} 
Nero's circle (Otho 2.1). Vespasian similarly owed his rise to his affair with Caenis, freedwoman of Antonia, mother of Claudius; he got his command in Britain through the influence of the freedman Narcissus; his membership of Nero's entourage was cut off when he fell asleep during Nero's singing. The doorman told him next morning he wasn't welcome, and when he asked where to go, the man replied, 'To Hell!' (Vesp. 3-4, with Dio). Vitellius' father was the perfect courtier: he carried one of Messalina's slippers in his toga, and would take it out and kiss it; he included images of the freedmen Narcissus and Pallas among his household gods (Vit. 2.5); the son obtained a leading place at court (praecipuum in aula locum) by his flexible propensity for the vice of the day, chariot-racing under Caligula, dicing under Claudius, and encouraging cithara playing under Nero (Vit. 4). Titus was brought up in court (educatus in aula) with Britannicus, step-brother of Nero; he was reclining at table next to Britannicus when the young prince was given his fatal draft of poison (Tit. 2).

Tittle-tattle this may all be, and Suetonius is regarded as less than serious for passing these stories on. But is there any reason to suppose that he and his sources were fantasising the whole set-up of a court society within which the ambitious networked, and made what connections they could, via women and freed slaves if appropriate, in order to achieve power and influence? The picture is abundantly confirmed by the other sources whom had good reason to be intimate with court life: Epictetus, former slave of Epaphroditus, potent freedman of Nero, who had to humiliate himself with his ex-slave Felicio, whom he had sold as good for nothing, became the emperor's cobbler; ${ }^{19}$ and Seneca, courtier to Claudius and Nero, whose philosophical writings are full of court anecdotes, including the reply of the aged courtier who when asked the secret of survival at court, replied 'By taking insults and returning thanks'. But it is not the anecdotes of Suetonius, Epictetus, and Seneca, nor even the resigned wisdom of Marcus Aurelius, that guarantees the importance of the imperial court, but its structural function.

The court, I propose, should be defined as the space around the ruler within which access to imperial favour is negotiated. The aula is not a building, though it has its monumental expression in the Palatium.

19 The relevance of Epictetus to understanding the court was shown by Fergus Millar, 'Epictetus and the Imperial Court', Journal of Roman Studies 55 (1965) pp. 141-148. 
Nor is it a legal or constitutional institution, such as Mommsen could recognize: the senate retained an institutional identity the court never had. Nor is it a bureaucracy, nor even the imperial household, whether the freeborn family members, domus Caesaris or the slave-born support system familia Caesaris. It is the space within which all these groups and institutions intersect in the pursuit of power.

As a space, it is fundamentally theatrical: it is where people come to see and be seen, and as in the theatre, to watch each other as well as the spectacle. They come to see the emperor and catch his eye; or catch the eye of those who know how to catch his eye; to observe their rivals catching eyes. It is consequently a dangerous space: everyone is visible, but everyone has something to hide from someone else. The fundamental feature of a democracy, and even of the Roman republic, whether we call that a democracy or not, is that power is pursued in the open, before the eyes of fellow citizens. However much you may depend on clientelism, you still have to bid for power openly in public, and win the votes of the people. At the imperial court, everything is veiled, only partially visible. However 'open' the court may have been in terms of access, this rendered the decision-making process no less covert: the openness of the social life stands in constant tension with the necessary veiling of the political process. ${ }^{20}$ The imperial decision is made public by a charade, public elections for the consuls from a closed list of preselected candidates. The court is where the decision is made: not in the sense of a specific place, but of the whole network of contacts and communications that spin a web around the emperor.

The most vivid statement of the theatrical nature of a court is the Duc de Saint Simon's account of the death of the son of Louis XIV, Monseigneur.

It must be admitted that, for him who is well acquainted with the privacies of a Court, the first sight of a rare event of this nature, so interesting in so many different respects, is extremely satisfactory. Every countenance recalls the cares, the intrigues, the labours employed in the advancement of fortunes-in the overthrow of rivals: the relations, the coldness, the hatreds, the evil offices done, the baseness of all; hope, despair, rage, satisfaction, express themselves in the features. See how all eyes wander to and fro examining what passes around-how some are

${ }^{20}$ A point made explicitly by Cassius Dio 53.19. Paterson, 'Friends in high places', p. 123 objects that the court was open and visible: he might not have convinced Tacitus. 
astonished to find others more mean, or less mean than was expected! Thus this spectacle produced a pleasure, which, hollow as it may be, is one of the greatest a Court can bestow. ${ }^{21}$

Specific observations of the varied reactions to the death bear out this general observation:

...Monseigneur was no more: it was known: it was spoken of: constraint with respect to him no longer existed. Amidst the surprise, the confusion, and the movements that prevailed, the sentiments of all were painted to the life in looks and gestures.

In the outside rooms were heard the constrained groans and sighs of the valets...Farther on began the crowd of courtiers of all kinds: The greatest number-that is to say the fools-pumped up sighs as well as they could, and with wandering but dry eyes, sung the praises of Monseigneur... Others, really afflicted-the discomfited cabal-wept bitterly, and kept themselves under with an effort as easy to notice as the sobs. The most strong-willed or the wisest, with eyes fixed on the ground, in corners, meditated on the consequences of such an event... Those who already looked upon the event as favourable in vain exaggerated their gravity so as to make it resemble chagrin and severity; the veil over their faces was transparent and hid not a single feature. ${ }^{22}$

Saint Simon's analysis, as Norbert Elias fully appreciated, underlines a fundamental feature of court life. ${ }^{23}$ Not only is it the place where the ruler and the elite keep each other under mutual observation, but where the elite watch each other, all competitors in the power game. And once that is understood, it is easier to appreciate that Tacitus too, for all his disdain, is a skilled and attentive observer of court life. One moment of drama and revelation that matches that of the death of the Monseigneur is the death of Britannicus. ${ }^{24}$ The young prince

${ }^{21}$ Memoirs of the Duke of Saint-Simon on the reign of Louis XIV. and the Regency, Bayle St. John, trans. (New York 1901) vol. 2, p. 378; see French original in fulltext online version: Saint-Simon, Louis de Rouvroy duc de, Mémoires complets et authentiques du Duc de Saint-Simon sur le siècle de Louis XIV et la régence, PierreAdolphe Chéruel, ed. (Paris 1856-58) 20 vols., vol. 9 chapter VI via http://rouvroy .medusis.com/.

${ }^{22}$ Saint-Simon, Memoirs, vol. 2, pp. 373-374, or vol. 9 chapter VI via http://rouvroy .medusis.com/

${ }^{23}$ Norbert Elias, Die höfische Gesellschaft. Untersuchungen zur Soziologie des Königtums und der höfischen Aristokratie (Darmstadt 1969), translated E. Jephcott, The Court Society (Oxford 1983).

${ }^{24}$ See Andrew Wallace-Hadrill, 'Rhetoric and Myth-Making at the Court of Nero', in: Neroniana VI: Rome à l'époque néronienne, Institutions et vie politique, économie et société, vie intellectuelle, artistique et spirituelle. Actes du VIe Colloque international de 
is dining at table with Nero, the other members of the imperial family, and various elite courtiers. Nero's poisoners choose ingeniously to administer the dose not in the wine, which is passed first to a taster, but in the cold water with which it is mixed. Britannicus at once suffers a seizure.

Trepidation spread among those sitting nearby, the foolish fled; both those with deeper understanding stayed immobile, with eyes fixed on Nero. He lay back as he was and as if he was unaware, remarked that it was usual for Britannicus to suffer epileptic fits from his infancy, and that his sight and senses would soon return. But with Agrippina such terror, such mental consternation, even though suppressed in her expression, flashed out as to make it clear that she was as innocent of the plot as his sister Octavia; indeed, she understood that her last help had been seized from her, and a precedent set for parricide. Octavia too, tender though her years, had already learned to conceal grief, affection, indeed every sentiment. (Ann. 13.16).

The imperial court seems several steps ahead of Versailles in the sophistication of its watching game. Everyone has learned to veil their feelings so effectively that the knowing eye only reads the truth through the very efforts of concealment.

Norbert Elias' analysis of the court of Versailles has come under heavy criticism in recent literature, not least for his excessive reliance on Saint Simon. In particular, his thesis that the court was the instrument whereby the king kept the nobility under watch and thereby under control, playing them off against their social rivals, is seen to be a model at best partly satisfactory for France, and not at all convincing for other courts. ${ }^{25}$ As study of the archives grows, so we can expect our understanding of the operation of such courts to become more nuanced, and above all to see that the ruler is as vulnerable as any other players, and that all the competing social elements gained as

la SIEN (Rome, 19-23 mai 1999), Jean-Michel Croisille et Yves Perrin, eds. (Collection Latomus vol. 268, Brussels 2002) pp. 472-478.

${ }^{25}$ See Aloys Winterling, Der Hof der Kurfürsten von Köln 1688-1794. Eine Fallstudie zur Bedeutung "absolutischer" Hofhaltung (Bonn 1986); Jeroen Duindam, Myths of Power: Norbert Elias and the Early Modern European Court (Amsterdam 1995); Jeroen Duindam, Vienna and Versailles: the Courts of Europe's Dynastic Rivals, 1559-1780 (Cambridge 2003); idem, 'Norbert Elias and the history of the court: old Questions, new perspectives', in: Hof und Theorie: Annäherungen an ein historisches Phänomen, R. Butz, J. Hirschbiegel and D. Willoweit, eds. (Cologne; Weimar; Vienna 2004) pp. 91-104. 
much as they lost. ${ }^{26}$ But this is perhaps where Tacitus, or Suetonius or Epictetus, can help us. They never suggest an emperor fully in control of his court. A Tiberius or a Nero emerges as fully vulnerable in these accounts, as much a victim as an instigator of the process of mutual watching. It is a dangerous game for all involved.

If we take the imperial court as the theatre where the elite of the empire assemble to watch each other, watch the power game, and take their chance, what consequences flow for its structural significance for the empire? Here it seems to me that in the very distaste for court life which Tacitus shared with Marcus Aurelius, historians have missed the fundamental contribution of the court. One of the most remarkable features of the Roman empire, and one that is basic to its long duration, is the ability to assimilate and draw into the centre of power the elites of geographically widespread and culturally diverse areas around the entire Mediterranean. Once we have got beyond the myths that the Empire owed its strength to legions (which were few) or to an efficient bureaucracy (which was virtually non-existent), we are thrown back on the willingness of local elites to collaborate with the Roman system. The successive waves by which provincials from different areas, first Spain and the western provinces, then Greece and Asia Minor, then the margins including Syria and the Balkans, penetrated to office and eventually imperial power, have been much documented, not least by Syme. The question is what mechanism allowed this penetration to happen? Popular elections in the city of Rome were the mechanism by which the Republican elite maintained its exclusivity and kept out newcomers.

The imperial court is the space within which newcomers gained access to power. Corrupt it may have been, and painful to those who found paying court to influential ex-slaves distasteful. But it drew together diverse elites from across the empire and enabled them to network, ally, and bargain. Its inherent instability was structurally incompatible with the long-term formation of stable elites. It promoted mobility, since the new arrivals have less baggage than the well-established, and are more alert to changing sides when the winds of fortune shift direction. ${ }^{27}$ Because loyalty to the emperor was everything, rises to fortune and power could be rapid and dramatic, whether the

${ }^{26}$ I am grateful to Jeroen Duindam for discussion of this point.

27 Cf. Keith Hopkins, Death and Renewal (Cambridge 1983) pp. 171-193. 
ex-slaves like Narcissus and Pallas who flourished under Claudius, or even the suave courtier Vitellius, who kissed Messalina's slippers, and was rewarded with a statue inscribed 'for unshakable loyalty to the emperor'. Undoubtedly, as Winterling has argued, the tendency was for the court to become more institutionalised over time; the rules of the game were better known in Marcus' court than in that of Tiberius. Yet its strength was its ability to exist outside institutions, outside the constitution. It provided an element of constant flexibility and change at the heart of the empire which contributed to its survival. 